\title{
Long-term haemodynamic evaluation of aortic pericardial xenograft
}

\author{
ANAND P. TANDON, DONALD R. SMITH, WILLIAM WHITAKER, \\ AND MARIAN I. IONESCU
}

From the Departments of Cardiology and Cardiothoracic Surgery, The General Infirmary, Leeds

SUMMARY Haemodynamic studies were performed in 30 patients at a mean interval of 43.4 (range 27 to 59) months after aortic valve replacements with pericardial xenografts. Five valve sizes-19, 21, 23, 25 , and $27 \mathrm{~mm}$ annulus diameter-were used. Of these 30 patients, 16 had preoperative haemodynamic investigations. Comparison of the pre- and postoperative data showed a marginal but significant increase in cardiac output $(P<0.05)$. There was a significant reduction in the pulmonary wedge and left ventri- $\frac{\rho}{9}$ cular end-diastolic pressures at rest and on exercise $(P<0.05$ and $P<0.01)$.

At the postoperative study the mean peak systolic gradient was $8.3 \mathrm{mmHg}$ at rest and $12.3 \mathrm{mmHg}$ on exercise in patients with the smallest xenograft inserted $(19 \mathrm{~mm})$ and decreased with each corresponding ${ }^{\Phi}$ increase in graft size, so that across the $27 \mathrm{~mm}$ graft it was hardly measurable. The calculated xenograft $\vec{\oplus}$ surface area ranged from $1 \cdot 1$ to $2 \cdot 1 \mathrm{~cm}^{2}$ at rest and 1.3 to $2.4 \mathrm{~cm}^{2}$ during exercise. Aortic root angiography 90 showed competent valves in all 30 patients, but a grade 1 to 2 perivalvular leak was shown in 8 patients.

This long-term study has indicated significant circulatory improvement and very small transvalvular gradients in patients with aortic pericardial xenografts.

Clinical results of heart valve replacement with glutaraldehyde stabilised pericardial xenografts have already shown a very good survival record, low thrombogenicity without anticoagulants, and maintenance of structural integrity of the grafts over a period in excess of $5 \frac{1}{2}$ years (Ionescu et al., 1977). Haemodynamic confirmation of the functional performance of the valve was necessary. This report presents the results of a late haemodynamic assessment of 30 patients who had aortic valve replacement with the Ionescu-Shiley pericardial xenograft. ${ }^{1}$

\section{Clinical background}

Since March 1971, 176 patients have had single aortic valve replacements with pericardial xenografts. The hospital and late mortalities were $6 \cdot 2$ and $5 \cdot 1$ per cent, respectively. Actuarial analysis of the expected survival rate and individual event-free curves for reoperation, bacterial endocarditis, and thromboembolism have been carried out by the method of Anderson et al. (1974) and the results are shown in Fig. 1. Of the total 176

${ }^{1}$ Shiley Laboratories, Irvine, California.

Received for publication 18 May 1977 patients, 17 had early diastolic murmurs. Peri- $\overrightarrow{\overrightarrow{0}}$ valvular leaks were confirmed in 14 patients either 3 at angiography (12 patients) or at reoperation ( 2 F patients). Clinically 96 per cent of patients are in grade 1 (NYHA) at the latest evaluation.

\section{Subjects and methods}

Haemodynamic investigations were performed in $30 \dot{\circ}$ patients at a mean interval of 43.4 (range 27 to 59 ) months, postoperatively. The criteria for selection 0 were an interval of at least 2 years from valve replacement and the informed consent of the patient. An effort was made to include patients with early diastolic murmurs in order to investigate them $ᄋ$ angiographically. In our belief, these 30 patients $N$ were in no other way different from the remaining uninvestigated patients with aortic pericardial $\sigma$ xenografts. The clinical details of the 30 patients studied are outlined in Table 1 . Additional mitral annuloplasty and implantation of permanent epicardial pacing systems were undertaken in 2 patients each at the time of the original operation. Of the 300 patients reported herein, 16 had preoperative cardiac catheterisations. The number of patients with different xenograft sizes is shown in Table 2.

All patients were admitted to hospital 24 hours< 


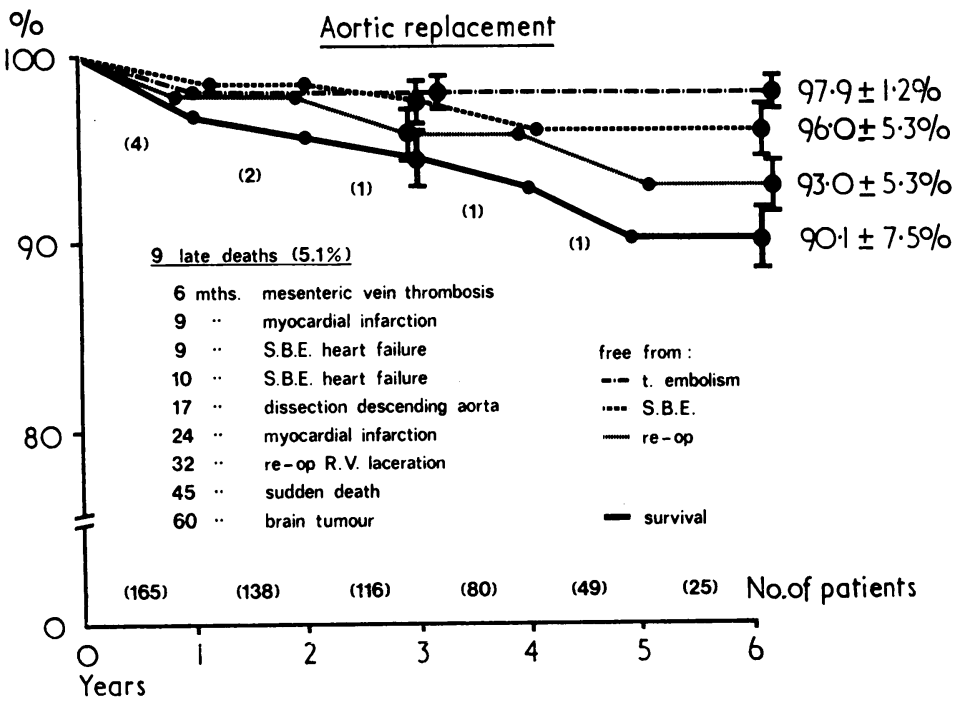

Fig. 1 Actuarial analysis of results after aortic pericardial xenograft valve replacement. The data are expressed as percentage of expected survival rate and individual event-free curves. The numbers in parentheses along the horizontal axis denote the number of patients at the beginning of each year.

Table 1 Preoperative clinical details of 30 patients

\begin{tabular}{ll}
\hline & No. of patients \\
\hline Male & 20 \\
Female & 10 \\
Age (years) & $49 \cdot 7$ \\
Mean & $( \pm 2 \cdot 4)$ \\
$\quad$ Range & $24-69$ \\
Preoperative clinical diagnosis & 15 \\
$\quad$ Stenosis & 10 \\
Regurgitation & 5 \\
Mixed valvular disease & 1 \\
New York Heart Association status & 16 \\
$\quad$ Grade 1 & 13 \\
$\quad$ Grade 2 & \\
\hline
\end{tabular}

before the haemodynamic study. On admission, a detailed clinical history, estimation of functional capability, physical examination, haematological assessment, a chest radiograph, a 12-lead electrocardiogram, and a phonocardiogram were obtained in all patients. Left ventricular voltage was measured by the sum of $S V_{1}$ and $R V_{5}$ from the electrocardiograms performed preoperatively and at the time of haemodynamic study. Right, retrograde left, and transseptal catheterisations were performed in the post-absorptive state without any previous sedation. Pulmonary and systemic pressures were transduced by strain-gauge manometers (SEM 486), integrated electronically, and recorded on a multichannel ultraviolet light recorder (SEM 3012) with the zero level set $5 \mathrm{~cm}$ below the sternal angle. Cardiac output was measured by the direct Fick method. Haemodynamic data were obtained during a 4minute period of rest and between the 4th and 6th minute of a 6-minute period of supine leg exercise on a bicycle ergometer at a predetermined maximal

Table 2 Postoperative haemodynamic data as related to xenograft size (mean values $\pm S E M$ )

\begin{tabular}{|c|c|c|c|c|c|c|c|c|c|c|c|c|c|c|}
\hline $\begin{array}{l}\text { Xenograft } \\
\text { size } \\
\text { (annulus } \\
\text { diameter } \\
\text { in } \mathrm{mm} \text { ) }\end{array}$ & $\begin{array}{l}\text { In vitro } \\
\text { surface } \\
\text { area } \\
\left(\mathrm{cm}^{2}\right)\end{array}$ & $\begin{array}{l}\text { No. of } \\
\text { patients }\end{array}$ & $\begin{array}{l}A V F \\
(\mathrm{ml} / \mathrm{s}) \\
R\end{array}$ & $E$ & $\begin{array}{l}P W P \\
(m m H g \\
R\end{array}$ & $E$ & $\begin{array}{l}L V E D \\
(m m H \\
R\end{array}$ & $E$ & $\begin{array}{l}P S G \\
(m m H \\
R\end{array}$ & $E$ & $\begin{array}{l}E S G \\
(m m F \\
R\end{array}$ & $E$ & $\begin{array}{l}X S A \\
\left(c m^{2}\right) \\
R\end{array}$ & $E$ \\
\hline 19 & 1.86 & 3 & $\begin{array}{l}192 \\
\pm 33.9\end{array}$ & $\begin{array}{l}249 \\
\pm 24 \cdot 0\end{array}$ & $\begin{array}{r}10.6 \\
\pm 1.8\end{array}$ & $\begin{array}{l}24 \cdot 5 \\
\pm 4 \cdot 1\end{array}$ & $\begin{array}{r}11 \cdot 3 \\
\pm 1.8\end{array}$ & $\begin{array}{l}25 \\
\pm 4.9\end{array}$ & $\begin{array}{r}8.3 \\
\pm 2.7\end{array}$ & $\begin{array}{r}12.3 \\
\pm 2.7\end{array}$ & $\begin{array}{r}14.3 \\
\pm 3 \cdot 2\end{array}$ & $\begin{array}{r}22.6 \\
\pm 6.4\end{array}$ & $\begin{array}{c}1.1 \\
\pm 0.07\end{array}$ & $\begin{array}{c}1.3 \\
\pm 0.07\end{array}$ \\
\hline 21 & $2 \cdot 38$ & 6 & $\begin{array}{l}194 \\
\pm 11.9\end{array}$ & $\begin{array}{l}282 \\
\pm 16 \cdot 5\end{array}$ & $\begin{array}{r}9.6 \\
\pm 1.4\end{array}$ & $\begin{array}{r}19 \cdot 3 \\
\pm 2.9\end{array}$ & $\begin{array}{r}10.6 \\
\pm 2.0\end{array}$ & $\begin{array}{r}20 \cdot 3 \\
\pm 3 \cdot 2\end{array}$ & $\begin{array}{r}7.9 \\
+1.6\end{array}$ & $\begin{array}{r}13 \cdot 3 \\
\pm 2 \cdot 3\end{array}$ & $\begin{array}{r}12.9 \\
\pm 1.2\end{array}$ & $\begin{array}{r}20 \cdot 3 \\
\pm 6 \cdot 2\end{array}$ & $\begin{array}{r}1.4 \\
\pm 0.1\end{array}$ & $\begin{aligned} & 1.8 \\
\pm & 0.03\end{aligned}$ \\
\hline 23 & 2.96 & 12 & $\begin{array}{l}204 \\
\pm 13.8\end{array}$ & $\begin{array}{l}324 \\
\pm 13 \cdot 2\end{array}$ & $\begin{array}{r}8.9 \\
\pm 0.5\end{array}$ & $\begin{array}{r}19.8 \\
\pm 0.4\end{array}$ & $\begin{array}{r}9.2 \\
\pm 0.5\end{array}$ & $\begin{array}{r}18.1 \\
\pm 1.9\end{array}$ & $\begin{array}{r}3.2 \\
\pm 1.6\end{array}$ & $\begin{array}{r}10.0 \\
\pm 2.6\end{array}$ & $\begin{array}{r}10.8 \\
\pm 1.6\end{array}$ & $\begin{array}{r}17.3 \\
\pm 1.6\end{array}$ & $\begin{array}{r}1.6 \\
\pm 0.1\end{array}$ & $\begin{array}{r}2.1 \\
\pm 0.1\end{array}$ \\
\hline 25 & 3.60 & 8 & $\begin{array}{l}260 \\
\pm 19 \cdot 3\end{array}$ & $\begin{array}{l}367 \\
\pm 22 \cdot 2\end{array}$ & $\begin{array}{r}9.5 \\
+1.1\end{array}$ & $\begin{array}{r}18.1 \\
\pm 1.6\end{array}$ & $\begin{array}{r}9.2 \\
\pm 0.6\end{array}$ & $\begin{array}{r}13.0 \\
\pm 1.9\end{array}$ & $\begin{array}{r}3.3 \\
\pm 1.1\end{array}$ & $\begin{array}{r}5 \cdot 7 \\
\pm 2.5\end{array}$ & $\begin{array}{r}7.5 \\
\pm 1.2\end{array}$ & $\begin{array}{r}13.0 \\
\pm 1.9\end{array}$ & $\begin{array}{c}1.8 \\
\pm 0.08\end{array}$ & $\begin{array}{r}2 \cdot 1 \\
\pm 0.1\end{array}$ \\
\hline $\begin{array}{l}27 \\
\text { All patient }\end{array}$ & $\begin{array}{l}4 \cdot 30 \\
\text { ts }\end{array}$ & $30^{1^{\star}}$ & $\begin{array}{r}196 \\
225 \\
\pm 11\end{array}$ & $\begin{array}{l}302 \\
322 \\
\pm 13 \cdot 7\end{array}$ & $\begin{array}{r}12 \\
9.4 \\
\pm 0.5\end{array}$ & $\begin{array}{l}19 \\
20 \cdot 3 \\
\pm 1 \cdot 1\end{array}$ & $\begin{array}{c}10 \\
9.9 \\
\pm 0.7\end{array}$ & $\begin{array}{l}15 \\
18 \cdot 3 \\
\pm 1 \cdot 6\end{array}$ & $\begin{array}{r}0 \\
6.4 \\
\pm 1.0\end{array}$ & $\begin{array}{r}1.0 \\
9.6 \\
+1.6\end{array}$ & $\begin{array}{c}5 \\
10.9 \\
\pm 0.9\end{array}$ & $\begin{array}{c}6 \\
16.9 \\
\pm 1.6\end{array}$ & $\begin{array}{c}2.1 \\
1.6 \\
+0.07\end{array}$ & $\begin{array}{r}2.4 \\
2.0 \\
\pm 0.1\end{array}$ \\
\hline
\end{tabular}

*Had additional mitral annuloplasty at the time of aortic valve replacement.

Abbreviations: R, rest; E, exercise; AVF, aortic valve flow; PWP, pulmonary wedge pressure; LVEDP, left ventricular end-diastolic pressure; PSG, peak systolic gradient; ESG, ejection systolic gradient; XSA, calculated xenograft surface area. 
Table 3 Pre-and postoperative haemodynamic data (mean values $\pm S E M$ and statistical significance)

\begin{tabular}{|c|c|c|c|c|c|c|c|c|c|c|}
\hline & \multicolumn{2}{|c|}{$\begin{array}{l}\mathrm{O}_{2} \text { uptake } \\
\left(\mathrm{ml} / \mathrm{min} \text { per } \mathrm{m}^{2}\right)\end{array}$} & \multicolumn{2}{|c|}{$\begin{array}{l}\text { Cardiac index } \\
\left(l / \min \text { per } m^{2}\right)\end{array}$} & \multicolumn{2}{|c|}{$\begin{array}{l}\text { Stroke index } \\
\left(\mathrm{ml} / \mathrm{m}^{2}\right)\end{array}$} & \multicolumn{2}{|l|}{$\begin{array}{l}P W P \\
(m m H g)\end{array}$} & $\begin{array}{l}\text { LVEDP } \\
(m m H g) \\
R\end{array}$ & $\boldsymbol{E}$ \\
\hline $\begin{array}{l}\text { Preoperative ( } 16 \text { patients) } \\
\text { Postoperative ( } 30 \text { patients) } \\
\text { P value }\end{array}$ & $\begin{array}{l}166.2 \\
\pm 12.5 \\
130.5 \\
\pm 2.7 \\
<0.01\end{array}$ & $\begin{array}{l}507 \cdot 8 \\
\pm 23 \cdot 1 \\
404 \cdot 1 \\
\pm 7 \cdot 9 \\
<0 \cdot 01\end{array}$ & $\begin{array}{r}2 \cdot 4 \\
\pm 0.2 \\
2 \cdot 7 \\
\pm 0 \cdot 1 \\
<0.05\end{array}$ & $\begin{aligned} & 4.2 \\
\pm & 0.3 \\
& 4.6 \\
\pm & 0.2 \\
< & 0.05\end{aligned}$ & $\begin{array}{l}29.2 \\
\pm 3.4 \\
40.4 \\
\pm 1.6 \\
<0.01\end{array}$ & $\begin{array}{l}33.6 \\
\pm 3.7 \\
46.5 \\
\pm 2.3 \\
<0.01\end{array}$ & $\begin{aligned} & 13.7 \\
& \pm 1.7 \\
& 9.4 \\
& \pm 0.5 \\
&<0.05\end{aligned}$ & $\begin{array}{l}31.4 \\
\pm 5 \cdot 2 \\
20.3 \\
\pm 1 \cdot 1 \\
<0.01\end{array}$ & $\begin{array}{r}19.1 \\
\pm 2.8 \\
9.9 \\
\pm 0.7 \\
<0.01\end{array}$ & 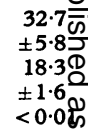 \\
\hline
\end{tabular}

SEM, standard error of the mean; PWP, pulmonary wedge pressure; LVEDP, left ventricular end-diastolic pressure; PSG, peak systolic građtent $R$, rest; E, exercise.

load. Aortic root angiography was performed in all patients at the end of the study.

Pulmonary and systemic vascular resistances were calculated using standard formulae. The ejection systolic gradient across the aortic pericardial xenograft was measured by planimetric integration of at least five simultaneously recorded phasic left ventricular and aortic root tracings. The pericardial xenograft surface area was calculated according to the hydraulic formula of Gorlin and Gorlin (1951) using the ejection systolic gradient.

\section{Results}

The details of the haemodynamic data are given in Tables 2 and 3 and Fig. 2 and 3.

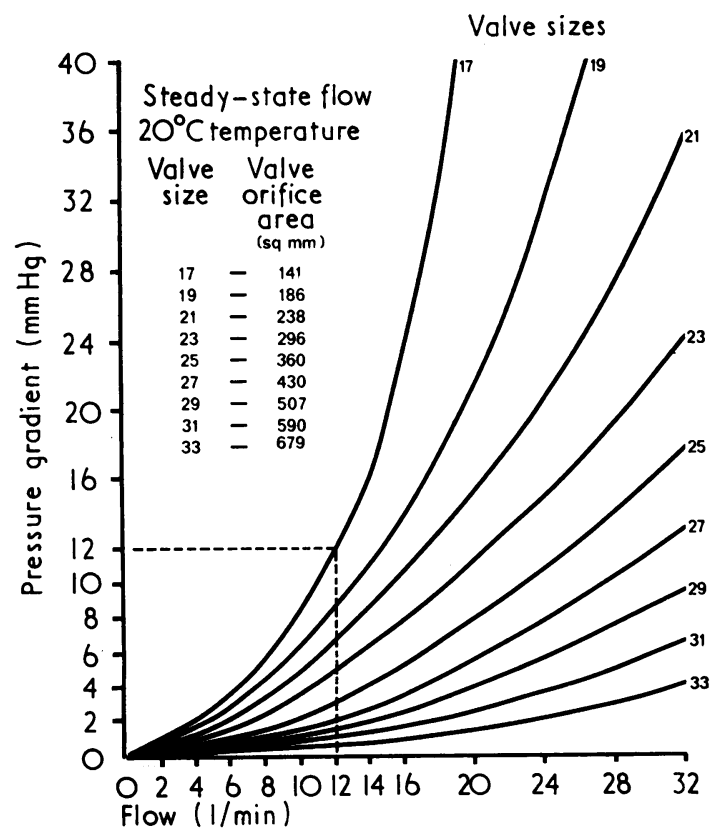

Fig. 2 In vitro flow and gradient across pericardial xenografts measured in a continuous flow rig. The curves represent mean values obtained from measurements made with at least two valves of each size.

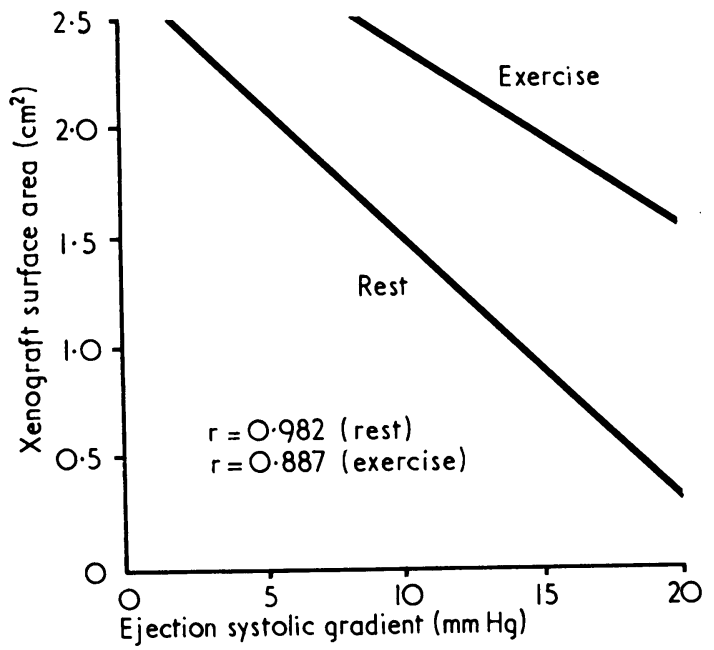

Fig. 3 Linear regression curve of ejection systolic gradient related to calculated xenograft surface area.

ELECTROCARDIOGRAPHIC AND

RADIOLOGICAL CHANGES

A highly significant reduction, from a preoperative mean value of $53.2( \pm 1.3)$ per cent to $47.7( \pm 0.9)$ per cent was noted in the cardiothoracic ratio at the postoperative study $(P<0.001)$.

The mean left ventricular voltage before operation was $50.3( \pm 2.3) \mathrm{mm}$ and showed a significant reduction to $34 \cdot 3( \pm 2 \cdot 1) \mathrm{mm}$ at the postoperative investigation $(P<0.001)$.

CARDIAC OUTPUT AND OXYGEN UPTAKE

The cardiac index showed a marginal but significant increase (Table 3 ) at the postoperative study both at 0 rest and during exercise $(P<0.05)$. Cardiac output response to exercise was normal. The oxygen uptake ? showed significant reduction both at rest and on exercise $(P<0.01)$.

The stroke volume at rest increased from the mean preoperative value of $29.2 \mathrm{ml} / \mathrm{m}^{2}$ to $40.4 \mathrm{ml} / \mathrm{m}^{2}$ at the postoperative study. A similar increase was noted during exercise. The increase in stroke 


\begin{tabular}{|c|c|c|c|c|c|}
\hline $\begin{array}{l}\text { PSG } \\
\text { ? } m m H g \text { ) } \\
?\end{array}$ & $E$ & $\begin{array}{l}\text { Vascular } r \\
\text { Pulmonary } \\
R\end{array}$ & $\begin{array}{l}\text { sistance } \\
E\end{array}$ & $\begin{array}{l}\left.s \mathrm{~cm}^{-5} m^{-2}\right) \\
\text { Systemic } \\
R\end{array}$ & $E$ \\
\hline $\begin{array}{c}83.3 \\
\pm 10.0 \\
6.4 \\
\pm 1.0 \\
<0.001\end{array}$ & $\begin{array}{l}- \\
- \\
9.6 \\
\pm 1.6\end{array}$ & $\begin{array}{c}231 \cdot 9 \\
\pm 34 \cdot 7 \\
239 \cdot 1 \\
\pm 15 \cdot 9 \\
\text { Not signif }\end{array}$ & $\begin{array}{r}216 \cdot 6 \\
\pm 23 \cdot 7 \\
171 \cdot 2 \\
\pm 19 \cdot 1 \\
\text { cant }\end{array}$ & $\begin{array}{r}2677 \cdot 2 \\
\pm 381 \cdot 6 \\
3024 \cdot 4 \\
\pm 140 \cdot 3\end{array}$ & $\begin{array}{r}2224 \cdot 3 \\
\pm 159 \cdot 2 \\
2290 \cdot 9 \\
\pm 107 \cdot 5\end{array}$ \\
\hline
\end{tabular}

volume both at rest and during exercise was significant $(P<0.01)$.

\section{PULMONARY WEDGE AND LEFT}

\section{VENTRICULAR END-DIASTOLIC PRESSURES}

Mean pulmonary wedge and left ventricular enddiastolic pressures were normal at rest at the postoperative study and the reduction from preoperative values was significant $(P<0.05$ and $P<0.01)$. The corresponding mean values during exercise, though abnormally high, showed a significant reduction when compared with the preoperative data $(\mathrm{P}<0.01)$.

\section{VASCULAR RESISTANCE}

No significant change was noted in either pulmonary or systemic vascular resistance at the postoperative study (Table 2).

\section{TRANSVALVULAR GRADIENT}

The hydraulic characteristics of the pericardial xenograft were studied in vitro. Pressure gradient was measured across the xenografts in a continuous flow rig and the results are shown in Fig. 2. At a flow of $12 \mathrm{l} / \mathrm{min}$, the gradient across the $17 \mathrm{~mm}$ valve was only $12 \mathrm{mmHg}$.

At the postoperative investigation both peak and ejection systolic gradients were measured in all patients. The mean values are shown in Tables 2 and 3.

The mean peak systolic gradient was $8.3 \mathrm{mmHg}$ at rest and $12.3 \mathrm{mmHg}$ on exercise in patients with xenograft size 19 and it decreased with the corresponding increase in the graft size, so that with the $27 \mathrm{~mm}$ graft it was hardly measurable. A highly significant correlation was noted between the peak systolic gradient and the annulus diameter of the xenograft $(r=0.954$ at rest and $r=0.937$ during exercise). A similar correlation was found between mean ejection systolic gradient and the xenograft size $(r=0.991)$.

\section{CALCULATED XENOGRAFT SURFACE AREA}

The calculated xenograft surface area varied from $1.0 \mathrm{~cm}^{2}$ to $2.6 \mathrm{~cm}^{2}$, the mean values being $1.6 \mathrm{~cm}^{2}$ at rest and $2.0 \mathrm{~cm}^{2}$ during exercise. Thus the cal- culated surface area increased during exercise with the increased flow. Further, the calculated value was lowest with the smallest xenograft implanted and rose with increasing xenograft size $(r=0.996$ at rest and $r=0.951$ during exercise). As shown in Table 2 the calculated areas in vivo are smaller than the in vitro surface area but a significant correlation was noted between the two values ( $r=0.995$ at rest and $\mathbf{r}=0.934$ on exercise).

Regression analysis showed a linear relation between the calculated xenograft surface area and the ejection systolic gradient as shown in Fig. 3.

\section{AORTIC VALVE FLOW}

The mean flows through the pericardial xenograft at rest and during exercise were $225 \pm 11$ and $322 \pm 13.7 \mathrm{ml} / \mathrm{s}$, respectively, at the postoperative study. The flows across various sizes of pericardial xenograft are given in Table 2. A significant correlation was noted between aortic valve flow and the annulus diameter of the xenograft implanted $(r=0.861$ at rest and $r=0.998$ during exercise).

\section{AORTOGRAPHY}

Aortic root angiography showed that all the pericardial xenografts studied were competent. Of the 30 patients, 8 were known to have early diastolic murmurs from the time of valve replacement. These showed grade 1 or 2 regurgitation of contrast material into the left ventricle (Brandt et al., 1969), the site of the regurgitation being clearly shown to be perivalvular on multiple plane angiograms. The haemodynamic data were not significantly different between the 8 patients with perivalvular leak and the remaining 22 .

\section{Discussion}

This long-term haemodynamic investigation has shown significant circulatory improvement after aortic valve replacement and maintenance of the function of the pericardial xenograft in the aortic position up to 59 months postoperatively.

The cardiac output showed a marginal but statistically significant increase and its response to exercise was normal. Oxygen utilisation improved after valve replacement. Similar findings have been reported by Olin (1970), Björk et al. (1971, 1974), Bristow and Kremkau (1975), Ionescu et al. (1974), and Dubiel and Cullhed (1975).

Pulmonary wedge and left ventricular enddiastolic pressures showed significant reduction both at rest and during exercise. The abnormal rise of these pressures during exercise appears to be related to the size of the xenograft inserted. How- 
Table 4 Postoperative haemodynamic data in patients with aortic valve substitute according to annulus diameter

\begin{tabular}{|c|c|c|c|c|c|c|c|c|c|c|c|c|c|}
\hline \multirow{3}{*}{$\begin{array}{l}\text { Authors } \\
\text { Björk (1970) }\end{array}$} & \multirow{3}{*}{$\begin{array}{l}\text { Valve substitute } \\
\text { Björk-Shiley valve }\end{array}$} & \multicolumn{6}{|c|}{ Peak systolic gradient } & \multicolumn{6}{|c|}{ Calculated surface area } \\
\hline & & 19 & 21 & 23 & 25 & $27 \dagger$ & Mean & 19 & 21 & 23 & 25 & $27 t$ & Mean \\
\hline & & 一 & $\begin{array}{c}21 \\
(39)\end{array}$ & $\begin{array}{c}17 \\
(20)\end{array}$ & $\begin{array}{c}7 \\
(10)\end{array}$ & $\begin{array}{c}11 \\
(17)\end{array}$ & $\begin{array}{l}12 \cdot 5 \\
(17)\end{array}$ & & & & & & \\
\hline Björk et al. (1971) & Björk-Shiley valve & 一 & 22 & $13 \cdot 8$ & $9 \cdot 3$ & $10 \cdot 7$ & & & $1 \cdot 3$ & $1 \cdot 7$ & $2 \cdot 2$ & $2 \cdot 4$ & 1.83 \\
\hline Sigwart et al. (1976) & Lillehei-Kaster valve & - & $30 \star$ & $32 \cdot 7^{\star}$ & $\begin{array}{l}21 \cdot 7^{\star} \\
(48 \cdot 5)^{\star}\end{array}$ & $14 \cdot 13$ & $\begin{array}{l}27 \cdot 11^{\star} \\
(48 \cdot 5)^{\star}\end{array}$ & & 0.94 & $1 \cdot 21$ & 1.56 & $1 \cdot 89$ & 1.6 \\
\hline Cohn et al. (1976) & Hancock porcine xenograft & & 21 & 20 & 10 & & 16 & & 1.05 & $1 \cdot 15$ & $1 \cdot 8$ & & $1 \cdot 4$ \\
\hline Morris et al. (1976) & Hancock porcine xenograft & & & & & & $\begin{array}{c}23 \\
(37)\end{array}$ & 0.99 & $1 \cdot 05$ & $1 \cdot 29$ & $1 \cdot 42$ & & $1 \cdot 25$ \\
\hline Hannah and Reis (1976) & Hancock porcine xenograft & & & & 26 & 14 & $\begin{array}{l}16 \\
(70)\end{array}$ & & & & & & \\
\hline Present series & $\begin{array}{l}\text { Ionescu-Shiley pericardial } \\
\text { xenograft }\end{array}$ & $\begin{array}{c}8 \cdot 3 \\
(12 \cdot 3)\end{array}$ & $\begin{array}{c}7 \cdot 9 \\
(13 \cdot 3)\end{array}$ & $\begin{array}{l}3 \cdot 2 \\
(10)\end{array}$ & $\begin{array}{c}3 \cdot 3 \\
(5 \cdot 7)\end{array}$ & $\begin{array}{c}0 \\
(1)\end{array}$ & $\begin{array}{c}6 \cdot 4 \\
(9 \cdot 6)\end{array}$ & $1 \cdot 1$ & $1 \cdot 4$ & $1 \cdot 6$ & $1 \cdot 8$ & $2 \cdot 1$ & $1 \cdot 6$ \\
\hline
\end{tabular}

The figures in parentheses are systolic gradients during exercise.

* Mean ejection systolic gradient.

Annulus diameter (mm) of the valve substitute.

ever, the number of patients in each subgroup is too small for this trend to be subjected to statistical analysis.

Published data regarding systolic gradient and calculated valve surface area with other currently used aortic valve substitutes are given in Table 4 . Pericardial xenografts, when compared with these valves, offer the least resistance to forward flow.

In the present investigation the systolic gradient was inversely related to the annulus diameter of the xenograft inserted. As expected, augmentation of the calculated xenograft surface area was noted with increasing annulus diameter of the valve.

Several authors (Cohn et al., 1976; Hannah and Reis, 1976; Jones, 1976; Morris et al., 1976) have commented on the high systolic gradients associated with the smaller sizes of Hancock porcine xenografts, and there is general agreement that for clinical use valves larger than $23 \mathrm{~mm}$ annulus diameter should be preferred for aortic valve replacement. High gradients have also been reported with the small sizes of Lillehei-Kaster prostheses. Nicoloff (1976) found a mean peak systolic gradient of $46 \mathrm{mmHg}$ (range 28 to 70 ) in 10 patients with No. 14 Lillehei-Kaster valve $(21 \mathrm{~mm}$ annulus diameter). Sigwart et al. (1976) propose that Lillehei-Kaster valves of at least $18 \mathrm{~mm}$ internal diameter ( $25 \mathrm{~mm}$ annulus diameter) should be used in the aortic position in adults in order to minimise prosthesis-induced stenosis.

Because of the high gradients produced by such valves, elaborate surgical manoeuvres have been advocated and used to enlarge the aortic annulus in order to accommodate a larger valve (Najafi et al., 1969; Nicks et al., 1970; Konno et al., 1975; Blank et al., 1976). The present study has established that the gradient across pericardial xenografts, even those of small size, is insignificant and therefore the insertion of this valve does not require additional surgical techniques for annulus enlargement. Consequently the use of the pericardial valve should be advantageous in patients with a small aortic annulus.

A separate series of sequential haemodynamic studies, performed at mean intervals of 9.9 and $42 \cdot 2$ months after aortic valve replacement, showed that the postoperative circulatory improvement was maintained and the transvalvular gradient did not change with the passage of time (Tandon et al., 1977).

This study has shown significant haemodynamic improvement as a result of aortic valve replacement with the Ionescu-Shiley pericardial xenograft and has substantiated the results of the clinical assessment. The transvalvular gradients are insignificant and predictable. Repeat circulatory studies are contemplated at longer intervals in order to assess continually the durability and functional performance of this valve.

\section{References}

Anderson, R. P., Bonchek, L. I., Grunkemeier, G. L., Lambert, L. E., and Starr, A. (1974). The analysis and presentation of surgical results by actuarial methods. fournal of Surgical Research, 16, 224-230.

Björk, V. O. (1970). A new central-flow tilting disc valve prosthesis: one year's clinical experience with 103 patients. fournal of Thoracic and Cardiovascular Surgery, 60, 355-371.

Björk, V. O., Henze, A., and Holmgren, A. (1974). Five years' experience with the Björk-Shiley tilting disc valve in isolated aortic valvular disease. Fournal of Thoracic and Cardiovascular Surgery, 68, 393-403.

Björk, V. O., Holmgren, A., Olin, C., and Ovenfors, C. O. (1971). Clinical and haemodynamic results of aortic valve replacement with Björk-Shiley tilting disc valve prosthesis. Scandinavian fournal of Thoracic and Cardiovascular Surgery, 5, 177-191.

Blank, R. H., Pupello, D. F., Bessone, L. N., Harrison, E. E., and Sbar, S. (1976). Method of managing the small aortic annulus during valve replacement. Annals of Thoracic Surgery, 22, 356-361. 
Brandt, P. W. T., Roche, A. H. G., Barratt-Boyes, B. G., and Lowe, J. B. (1969). Radiology of homograft aortic valves. Thorax, 24, 129-141.

Bristow, J. D., and Kremkau, E. L. (1975). Hemodynamic changes after valve replacement with Starr-Edwards prostheses. American fournal of Cardiology, 35, 716-724.

Cohn, L. H., Sanders, J. H., and Collin, J. J. (1976). Aortic valve replacement with the Hancock porcine xenograft. Annals of Thoracic Surgery, 22, 221-225.

Dubiel, W. T., and Cullhed, I. (1975). Aortic valve replacement with frame supported autologous fascia lata grafts. III. Haemodynamic and angiographic findings. Scandinavian fournal of Thoracic and Cardiovascular Surgery, 9, 120-132.

Gorlin, R., and Gorlin, N. G. (1951). Hydraulic formula for calculation of the area of the stenotic mitral valve, other cardiac valves, and control circulatory shunts. American Heart fournal, 41, 1-29.

Hannah, H., III., and Reis, R. L. (1976). Current status of porcine heterograft prostheses: a 5-year appraisal. Circulation, 54, Suppl. III, 27-31.

Ionescu, M. I., Pakrashi, B. C., Mary, D. A. S., Bartek, I. T., and Wooler, G. H. (1974). Long term evaluation of tissue valves. Fournal of Thoracic and Cardiovascular Surgery, 68, 361-378.

Ionescu, M. I., Tandon, A. P., Mary, D. A. S., and Abid, A. (1977). Heart valve replacement with the Ionescu-Shiley pericardial xenograft. Fournal of Thoracic and Cardiovascular Surgery, 73, 31-41.

Jones, E. L. (1976). In discussion of paper by: Blank, R. H., Pupello, D. F., Bessone, L. N., Harrison, E. E., and Sbar, S. Methods of managing the small aortic annulus during valve replacement. Annals of Thoracic Surgery, 22, 356-361.

Konno, S., Imai, Y., Iida, Y., Nakajima, M., and Tatsuno, K. (1975). A new method for prosthetic valve replacement in congenital aortic stenosis associated with hypoplasia of the aortic valve ring. Fournal of Thoracic and Cardiovascular Surgery, 70, 909-917.

Morris, D. C., Wickliffe, C. W., King, S. B., Douglas, J. S., and Jones, E. L. (1976). Hemodynamic evaluation of the porcine xenograft aortic valve (abstract). American fournal of Cardiology, 37, 157.

Najafi, H., Ostermiller, W. E., and Javid, H. (1969). Narrow aortic root complicating aortic valve replacement. Archives of Surgery, 99, 690-694.

Nicks, R., Cartmill, T., and Bernstein, L. (1970). Hypoplasia of the aortic root. Thorax, 25, 339-346.

Nicoloff, D. M. (1976). In discussion of paper by: Starek, P. J. K., McLaurin, L. P., Wilcox, B. R., and Murray, G. F. Clinical evaluation of the Lillehei-Kaster pivoting-disc valve. Annals of Thoracic Surgery, 22, 362-368.

Olin, C. (1970). Evaluation of the Kay-Shiley disc valve prosthesis in the aortic position. Scandinavian fournal of Thoracic and Cardiovascular Surgery. Suppl. 7.

Sigwart, U., Schmidt, H., Gleichmann, U., and Borst, H. G. (1976). In vivo evaluation of the Lillehei-Kaster heart valve prosthesis. Annals of Thoracic Surgery, 22, 213-220.

Tandon, A. P., Smith, D. R., Mary, D. A. S., and Ionescu, M. I. (1977). Sequential hemodynamic studies in patients having aortic valve replacement with the Ionescu-Shiley pericardial xenograft. Annals of Thoracic Surgery, 24, 149-155.

\section{Addendum}

Since the preparation of this manuscript, in November 1976, the number of patients who received aortic pericardial xenograft valves has increased to 216 and 6 more patients had haemodynamic investigations. The clinical results of the entire series, at 7 years follow-up, are essentially similar to those described in this paper.

Requests for reprints to M. I. Ionescu, Esq., F.A.C.S., Department of Cardiothoracic Surgery, The General Infirmary, Leeds LS1 3EX. 